\title{
Tolerance and immunity to pathogens in early life: insights from $\mathrm{HBV}$ infection
}

\author{
Michelle Hong ${ }^{1}$ - Antonio Bertoletti ${ }^{1,2}$
}

Received: 7 May 2017 / Accepted: 19 June 2017 / Published online: 6 July 2017

(C) The Author(s) 2017. This article is an open access publication

\begin{abstract}
Immunity is not static but varies with age. The immune system of a newborn infant is not "defective" or "immature." Rather, there are distinct features of innate and adaptive immunity from fetal life to adulthood, which may alter the susceptibility of newborn infants to infections compared to adults. Increased protection to certain infectious diseases during early life may benefit from a dampened immune response as a result of decreased immune pathology. This concept may offer an alternative interpretation of the different pathological manifestations clinically observed in hepatitis B virus (HBV)-infected patients during the natural history of infection. Herein, we review the immune pathological features of HBV infection from early life to adulthood and challenge the concept of a generic immune tolerant state in young people. We then discuss how the different clinical and virological manifestations during HBV infection may be related to the differential antiviral immunity and pro-inflammatory capacity generated at different ages. Lastly, we address the potential to consider earlier therapeutic intervention in HBVinfected young patients to achieve effective immune control leading to better outcomes.
\end{abstract}

This article is a contribution to the special issue on Immunocompetence of the Newborn - Guest Editors: Arnaud Marchant and Tobias Kollmann

Michelle Hong

michelle.hong@duke-nus.edu.sg

1 Emerging Infectious Diseases (EID) Program, Duke-NUS Medical School, 8 College Road, Singapore 169857, Singapore

2 Viral Hepatitis Laboratory, Singapore Institute for Clinical Sciences, Agency of Science Technology and Research (A*STAR), Singapore, Singapore
Keywords Hepatitis B virus · Vertical transmission · Immune tolerance $\cdot \mathrm{HBV}$-specific T cells $\cdot$ Liver inflammation . Trained immunity

\section{HBV viral transmission and disease burden}

Mother-to-child transmission of viruses (transplacental, perinatal, or postnatal) is often associated with higher levels of viral replication, a greater risk of persistent or chronic infection, and more severe disease outcome compared to those acquired during adulthood [1]. Hepatitis B virus (HBV), among the intracellular pathogens which can be acquired through mother-to-child transmission, causes one of the most common infectious diseases in the world.

HBV is a hepatotropic, non-cytopathic, DNA virus that chronically infects approximately 240 million people worldwide $[2,3]$, with liver-related morbidity and mortality due to chronic hepatitis B (CHB) including cirrhosis and hepatocellular carcinoma accounting for more than 600,000 deaths per year [4]. HBV infection causes acute or chronic liver diseases characterized by different levels of liver inflammation and viral replication, which in turn, is determined by a complex interplay of host and viral factors including host genetic background, dose or route of infection, viral genotype, and importantly, the age of acquisition $[5,6]$. The risk of developing chronic infection is the highest following vertical or perinatal infection (90\%) compared to those infected between the ages of 1 and 5 years $(20-30 \%)$ or during adulthood $(<5 \%)[7,8]$. In regions of high endemicity, including Asia and sub-Saharan Africa, virus transmission from mother-to-child at birth is the major cause of HBV chronicity. Despite the development of an effective HBV prophylactic vaccine $[9,10]$, the prevalence of the virus continues to increase [3]. 


\section{Triggering immunity and tolerance to $\mathrm{HBV}$}

HBV infection, unlike many other viruses, is characterized by a delayed kinetics of viral replication and spread. Experimental data collected, mainly in animal models but also in humans [11], showed that HBV replication is detectable in the serum or the liver of infected host only 4-7-week postinfection [11-16] (Fig. 1). Following this period, HBV enters a logarithmic phase of expansion, reaching $10^{9}-10^{10}$ copies $/ \mathrm{ml}$ in the liver and serum [17], and infecting most hepatocytes [11, 13-16] (Fig. 1). A further unique characteristic of HBV is its inability to trigger a classical innate immune response. Data in vitro and in vivo has shown the absence of activation of type I IFN genes during the logarithmic phase of HBV expansion and the absence of pro-inflammatory cytokines in the serum of patients in the early phases of acute infection. The causes of this inability of HBV to activate a classical innate immune response and whether HBV actively suppress innate immunity or only evade its recognition have been highly debated and have been reviewed elsewhere [18].

$\mathrm{HBV}$ is, however, able to trigger a functional and efficient adaptive immune response characterized by the presence of HBV-specific antibodies and $\mathrm{T}$ cell response in most of the patients infected horizontally. In this case, $\mathrm{T}$ cell response develops before the peak of acute hepatitis and is preceded by the production of IFN- $\gamma$ within the hepatic parenchyma, which has been suggested to indicate a possible natural killer (NK) or NK-T cell activation. Such induction of a robust and multi-specific antiviral $\mathrm{T}$ cell response is necessary for the control of the infection, and deletion of $\mathrm{CD} 8^{+} \mathrm{T}$ cells in acutely infected chimpanzees demonstrates the pivotal role of these components of the immune system in HBV control.

The majority of infections acquired at birth or perinatally develops instead into chronic infection that are characterized by a profound defect of $\mathrm{HBV}$-specific $\mathrm{T}$ cell response, with lower numbers of circulating and intrahepatic HBV-specific $\mathrm{CD}^{+}$and $\mathrm{CD}^{+}{ }^{+} \mathrm{T}$ cells, as well as lower and restricted production of HBV-specific antibody [19] (Fig. 1). The reason why the virus is unable to trigger an efficient antiviral immunity under such circumstances is open to debate. It is interesting to point out that neonatally infected woodchucks that develop chronicity lack the IFN- $\gamma$ and TNF- $\alpha$ surge [20-22] which is present in animals that are able to control the infection, and fail to develop an efficient antiviral specific immune response. Presentation of HBV antigens by hepatocytes in the absence of pro-inflammatory response may induce a defective $\mathrm{T}$ cell response that is further depleted by prolonged exposure to large quantities of soluble HBV antigens (HBeAg and HBsAg) [23].

$\mathrm{HBeAg}$, a secretory form of the nucleocapsid antigen or core antigen, is produced in large excess during HBV replication [24]. The tolerizing effect of $\mathrm{HBeAg}$ has been well characterized in mice [25-27] and likely contributes to the low level of core-specific $\mathrm{T}$ cell responses present in $\mathrm{HBeAg}^{+}$ chronic patients. Soluble form of HBsAg is also produced in excessive amounts during HBV replication. HBV particles composed of only HBsAg are produced up to $10^{3}-10^{6}$-fold excess over whole virions and can reach $1-10 \mu \mathrm{g} / \mathrm{ml}$ in the serum [24]. Such persistently high viral antigen load allows cross-presentation by liver professional antigen-presenting cells (Kupffer cells, liver endothelial cells), which can induce tolerance in chronic HBV patients [28]. Furthermore, direct presentation of foreign antigen by hepatocytes has been suggested to preferentially induce $\mathrm{CD} 8^{+} \mathrm{T}$ cell tolerance, resulting in reduced $\mathrm{CD} 8^{+} \mathrm{T}$ cell clonal expansion and increased $\mathrm{T}$ cell apoptosis [28]. Other factors, such as dendritic cell functional alteration and $\mathrm{T}$ regulatory cells (Tregs), have been suggested to contribute to virus-specific T cell tolerance in chronic HBV patients. However, the evidence supporting the role of dendritic cells or Tregs in the induction of antigen-specific tolerance remains controversial [29].

\section{Does vertical HBV transmission induce immune tolerance?}

Chronic HBV infection, particularly in Asia, is caused by mother-to-child transmission of the virus. HBV infection in infants or young children is usually asymptomatic until late adulthood, when it causes liver pathologies (cirrhosis and hepatocellular carcinoma) [3]. To explain this dichotomy, HBV is thought to "hijack" the immaturity of the neonatal immune system and/or to induce an "immunotolerant phase" of disease - characterized by high HBV DNA levels, positive hepatitis $\mathrm{B}$ e antigen ( $\mathrm{HBeAg}$ ), normal or low serum alanine aminotransferase (ALT) levels, and minimal or no liver
Fig. 1 Kinetics of HBV replication and host immune response in self-limited versus chronic infection. Coordinated activation of both innate and adaptive immunity is necessary for successful control of HBV. $H B V$ hepatitis B virus, $W H V$ woodchuck hepatitis virus
Self-limited acute infection

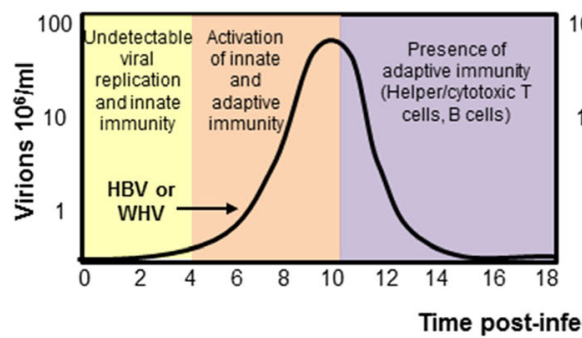

Chronicinfection

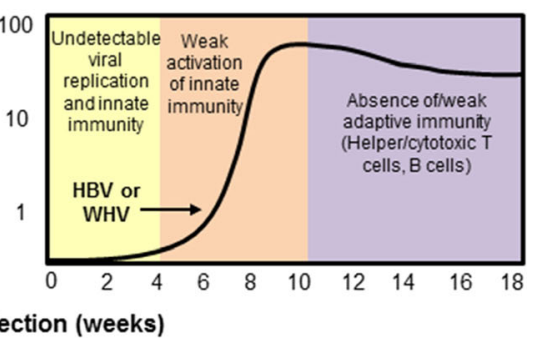


inflammation that usually lasts from a few years to several decades without disease progression $[5,7,30]$.

This immunotolerance hypothesis is mainly supported by data from experimental animal models (i.e., HBV transgenic animals) that showed the presence of immunological defects which impair HBV-specific $\mathrm{T}$ and $\mathrm{B}$ cell priming in neonatal animals $[27,31,32]$, thus predisposing to HBV chronicity. A recent study by Tian et al. [33] showed that the qualitative and quantitative defects detected in $\mathrm{HBV}$-specific $\mathrm{CD}^{+} \mathrm{T}$ cells in vertically infected neonatal mice were associated with inhibitory responses exerted by hepatic macrophages, leading to increased risk of vertical transmission and development of chronicity. While these data are methodologically robust, their significance in relation to HBV pathogenesis remains questionable, since the data supporting such immunological features are derived exclusively from HBV transgenic animals that do not support natural HBV infection. Instead, HBV virions are produced from $\mathrm{HBV}$ transgenes introduced into the mouse genome under the control of hepatocyte-specific promoter, and as such cannot fully recapitulate the natural course of HBV infection. Certainly, a lack of appropriate animal models represents a major hurdle to study immunotolerance in HBV [34].

The concept that the neonatal immune response is somehow "defective" or "immature" is also changing, and there is mounting evidence showing that the neonatal immune responses defy such simple categorization. In fact, neonates seem to embody the full spectrum of immune responses, including immune effectors and regulatory responses, during early life [35-37], and they are neither "immunodeficient" nor "immature." Newborn infants have also been shown to harbor the ability to mount virus-specific T cell response towards viral infections in early life [38-40]. For example, Luzuriaga et al. demonstrated that HIV-1-specific T cells can be detected in some young infants, and even the fetus [38]. Studies of congenital CMV infection showed that high frequencies of $\gamma \delta$ and $\alpha \beta$ T cells can be induced early during fetal life [39, 40].

Furthermore, exposure of the newborn immune system towards microbes at birth can also shape the maturation status of the newborn infant. Epidemiological and experimental evidences have shown that exposure to bacterial or viral infections after birth and vaccination with live vaccines can protect infants against unrelated pathogens by inducing an increased functional efficiency of their innate immune system through a process known as "trained immunity" [41]. For example, BCG vaccination in newborn children in West Africa is associated with reduced all-cause mortality, largely due to infections other than tuberculosis, in the first month of life [42]. Similar observations have also been made for vaccination with vaccinia virus [43] or with measles vaccine [44], which showed important non-specific protective effects. Further evidence that trained immunity could be clinically relevant in vivo during early life is exemplified by the diminished risk of late-onset sepsis (i.e., after $72 \mathrm{~h}$ of life) among very premature infants with early-onset sepsis (i.e., within the first $72 \mathrm{~h}$ of life) [45]. All these earlier reports indicate that the immune system of newborn infants is not "immature" or "defective" per se, and that the innate immune system could display memory features right from birth. Furthermore, the newborn immune system appears to be less prone to trigger a full-blown pro-inflammatory reaction, likely as an evolutionary adaptation to prevent undesirable immune reactions in utero.

Therefore, the hypothesis that vertical HBV infection induces a state of general immunotolerance, the basis of which the disease is managed and treatment decisions are made, remains controversial. Although the immunological data both during and after natural vertical HBV infection is limited, several epidemiological and experimental evidences can be used to challenge this concept of immunotolerance. For example, the functionality of dendritic cells is intact or minimally altered in neonates of $\mathrm{HBV}^{+}$mothers [46-48]. Furthermore, $\mathrm{T}$ cells specific for the HBV core and polymerase antigens (antigens not present in the HBV prophylactic vaccine) have been detected in $\mathrm{HBsAg}^{-}$children born to $\mathrm{HBV}^{+}$mothers in two independent studies $[49,50]$. This shows that neonates born to $\mathrm{HBV}^{+}$mothers do not necessarily harbor defects in $\mathrm{T}$ cell priming. On the contrary, they have the ability to prime HBV-specific T cell responses. Analysis of HBV quasispecies in children with a clinical profile labeled as immunotolerant showed a high HBV diversity [51], a virological profile that is compatible with the presence of an active immune pressure and not with complete immune tolerance during this initial phase of infection.

Besides, the efficacy of HBV vaccination at birth in children of $\mathrm{HBV}^{+}$mothers $[52,53]$ raises doubts that the state of complete HBV immune tolerance and the broad defects in $\mathrm{T}$ and $\mathrm{B}$ cell interaction detected in murine models exist during natural infection. The dogma of immunotolerance in vertical $\mathrm{HBV}$-infected children is also in contrast to epidemiological observations showing higher frequency of HBV-related fulminant hepatitis in infants $<1$ year of age compared to that in older subjects [54], and with the observations obtained from malaria-HBV co-infected young patients in whom reduced parasitemia [55] and increased incidences of cerebral malaria [56], a Th1-mediated malaria complication, have been reported. Such observations are more suggestive of the possibility of an alternative relationship between HBV and humans during early life, i.e., HBV may play more than just a pathogenic role in humans.

An indirect demonstration of this alternative relationship between HBV and humans comes from our recent work where we performed a detailed characterization of the immunological parameters in the cord blood of neonates born to $\mathrm{HBV}^{+}$ mothers. Contrary to the dogma of generic immunotolerance, we found that HBV exposure in utero triggers a state of 
"trained immunity," characterized by increased innate immune cell activation and Th1 development, which in turn enhances the ability of HBV-exposed cord blood immune cells to respond to bacterial infection in vitro [57] (Fig. 2). These training effects are associated with alterations in the cytokine environment. Specifically, we detected, in the sera of HBV-exposed neonates, a cytokine signature compatible with a Th1-like response with higher production of IL12 p40 and in some cases IFN- $\alpha 2$, lower production of IL-10 and pro-inflammatory cytokines (such as IL-6, IL-8, and TNF- $\alpha$ ). This Th1 cytokine signature is more suggestive of a symbiotic relationship between HBV and humans during early life, similar to that already demonstrated in murine models of herpesvirus-persistent infection [58], than to the induction of a tolerogenic response. HBV-specific T cells were not detected in the cord blood of HBV-exposed neonates; therefore, the possibility that HBV vertical infection might tolerize $\mathrm{HBV}$-specific immunity cannot be excluded.
Nevertheless, the induction of a trained immunity profile with a general Th1 response and suppression of proinflammatory events in HBV-exposed neonates show that the neonatal immune system can be "trained" by HBV exposure and further activated to possibly counteract unrelated pathogens during early life.

\section{Immunological and virological events during the "immunotolerant" phase of HBV infection}

Most of the evidences supporting an immunotolerance disease phase of HBV infection during early childhood are based on clinical and virological parameters. HBV is not directly cytopathic, and $\mathrm{HBV}$-specific $\mathrm{CD} 8^{+} \mathrm{T}$ cells control virus replication by recognizing and killing $\mathrm{HBV}$-infected hepatocytes [16]. ALT is released from dying hepatocytes, and thus, serum
Fig. 2 Induction of trained immunity in human neonates of $\mathrm{HBV}^{+}$mothers. $\mathrm{HBsAg}^{+}$cells can be detected in the cord blood of neonates born to HBV-infected mothers, demonstrating in utero exposure to viral products. These $\mathrm{HBsAg}^{+}$cells could be due to transplacental passage of maternal $\mathrm{HBsAg}^{+}$cells or active uptake of serum HBsAg by neonatal cells. $\mathrm{HBV}$ exposure in utero is associated with significantly elevated plasma levels of the antiviral cytokine IL-12p40, and in some cases, IFN- $\alpha 2$. Exposure to $\mathrm{HBV}$ in utero also induces innate immune cell (monocytes, NK cells) maturation/activation and enhances Th1 T cell development. Importantly, this heightened state of innate immune functionality results in a stronger ability of neonatal immune cells to respond to unrelated pathogen challenge - a process known as "trained immunity"

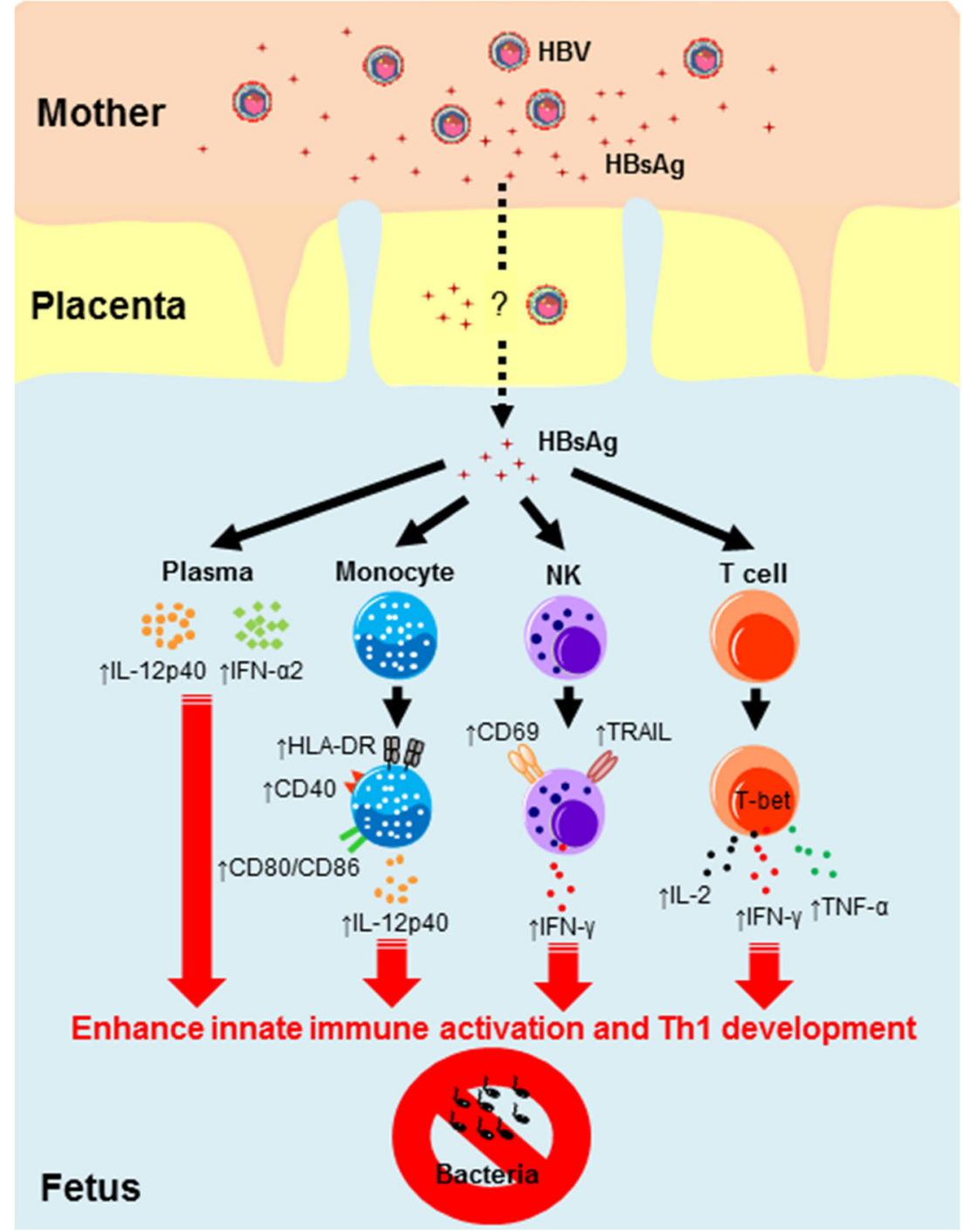


ALT has been interpreted as a marker of immune activity, i.e., the presence or absence of ALT fluctuations correlates with the presence or absence of HBV-specific T cells. In this context, normal or minimal alterations in ALT levels, detectable in the majority of HBV-infected children, have been perceived as an indication of lack of HBV-specific T cell response. On the other hand, fluctuations in the levels of ALT and HBV DNA replication, more commonly observed during adulthood, is interpreted as an "awakening" of HBV-specific immunity.

Here lies a fundamental problem - the use of a clinical categorization to define a disease state in an immunemediated liver condition is inappropriate and inaccurate. In reality, both experimental data in animal models and in humans during natural HBV infection have shown that ALT measurement cannot be used as a reliable surrogate of virusspecific T cell responses. Studies performed in adenovirusinfected mice have shown that $\mathrm{T}$ cell immunity against hepatocytes could occur without elevation in serum ALT level [59]. Furthermore, adoptive transfer of HBV-specific T cells can lead to significant inhibition of HBV replication without increase in serum ALT through cytokine-mediated non-cytopathic effect [60]. Direct quantification of HBV-specific T cells in the blood and liver of CHB patients have also shown that, in contrast to patients with acute hepatitis B [61], the quantity of HBV-specific $\mathrm{T}$ cells does not correlate with ALT levels $[62,63]$. Instead, robust inflammatory events in the liver causing fluctuations in ALT levels, demonstrated both in adult mice and in patients, are associated with intrahepatic recruitment of granulocytes, monocytes, and non-antigen-specific T cells [62, 64, 65].

There is also mounting evidence showing that surrogate markers such as ALT might not reflect the true disease status, and what constitutes a normal or healthy ALT level continues to be debated. The new cut-off value recommended as healthy by Prati et al. [66], i.e., $\leq 30 \mathrm{U} / 1$ for men and $\leq 19 \mathrm{U} / 1$ for women, is higher than the traditional cut-off value of $40 \mathrm{U} / \mathrm{l}$, but the upper limit of normal for children has not been established. Therefore, even a slight increase in serum ALT may reflect changes in immune activity and disease profile [67]. For instance, it has been reported that substantial fibrosis and necroinflammatory activity already exist in the liver biopsy of some patients in the "immunotolerant" phase with the traditional serum ALT cut-off value of $40 \mathrm{U} / 1$ [68].

The concept of immune tolerance phase being a quiescent disease phase with an absence of virus-specific $\mathrm{T}$ cells and minimal changes in liver histology is now increasingly being challenged. Our recent study of chronic hepatitis B-infected children and young adults with a clinical and virological profile labeled as "immunotolerant" showed the existence of HBV-specific T cell responses that is less compromised than that observed in CHB-infected adult patients in the "immune clearance" phase [69]. A further demonstration that these patients do not display any generic state of immunotolerance was exemplified by the superior ability of circulating $\mathrm{T}$ cells from young IT patients with CHB to produce type $1 \mathrm{~T}$-helper cytokines including TNF- $\alpha$ and IFN- $\gamma$, compared to agematched healthy controls. On the other hand, the production of immunosuppressive cytokines including IL-10 and IL-4 was not elevated in these patients. Detailed analysis of the phenotype of T cells in these patients showed that young IT patients with CHB have a partially exhausted $\mathrm{T}$ cell profile, compared to adult patients with a more exhausted $\mathrm{T}$ cell profile $\left(\mathrm{CD} 8^{+} \mathrm{T}\right.$ cells that are PD- $1^{+}$and $\left.\mathrm{CD} 127^{\mathrm{lo}}\right)$. This could explain why older patients have a less favorable response to therapy, and suggest that earlier therapeutic intervention may be more advantageous in young people who lack a fully exhausted $\mathrm{T}$ cell profile.

Similarly, new data from Mason et al. further strengthen the concept that ongoing disease activity already exists in the liver of CHB patients during the "immunotolerant" phase [70]. For instance, Mason et al. reported an unexpectedly high number of HBV DNA integration sites randomly distributed across the human chromosome in patients clinically labeled as "immunotolerant," comparable to those observed in patients with $\mathrm{HBeAg}{ }^{+}$disease or those in the immune clearance phase. Viral DNA integration and the resulting genomic instability is associated with the risk of developing hepatocarcinogenesis, with $80 \%$ of HBV-related HCC demonstrating clonal integrated HBV sequences [71]. In addition to HBV DNA integration, clonal hepatocyte expansion was also detected in "immunotolerant" patients at an unexpectedly high rate [70]. Clonal expansion of hepatocytes, a risk factor for the development of HCC, probably occurs in response to hepatocyte turnover mediated by HBV-specific T cell killing of infected hepatocytes, since HBV-specific T cells were detected in the peripheral blood of these patients. Furthermore, the maximum hepatocyte clone size did not differ between the "immunotolerant" patients and those with $\mathrm{HBe}^{+}$disease or in the immune clearance phase. All these findings demonstrate that promoters of oncogenesis exist in all phases of CHB infection, even in patients at the early stage of CHB infection traditionally considered "immunotolerant."

Collectively, our findings, together with others in the field, do not support the notion that the initial "immunotolerant" phase is completely devoid of markers of disease progression or that there is a lack of immune response. Like in all patients with chronic HBV infection, adaptive immunity is compromised in this phase, but not more than in the others. Hence, this so-called immunotolerant phase, characteristically associated with infection acquired during early life, has now been defined as $\mathrm{HBeAg}^{+}$chronic infection according to the recent EASL guidelines to better reflect the immunological events occurring during natural HBV infection. However, arguments against such new definitions have raised an interesting debate [72, 73]. 
Age-related changes in immunity and inflammatory responses during viral infections

It is well described that there are clear age-related differences in response to vaccines between early life and adulthood, but whether similar differences exist during natural infection with pathogenic microorganisms remains poorly defined [37]. In the context of HBV infection, we have reviewed the clinical and experimental evidences showing that the initial "immunotolerant" phase of chronic HBV infection (now defined as $\mathrm{HBeAg}{ }^{+}$chronic infection) is no longer considered to be quiescent, as the detection of HBV-specific T cells and liver damage point to underlying disease and immune activity. As such, how can we explain the different virological and inflammatory profiles during the natural history of HBV infection?

A possible explanation is that there are developmental differences in the immune function between infants/young children and adults. This concept is well established for adaptive immunity, but increasingly, it is appreciated that the innate immune function also changes with age. While the expression of TLR is similar in early versus adult life, TLR-mediated production of cytokines follows a developmental pattern: the production of anti-inflammatory cytokines (e.g., IL-10) is high in pre-term infants, then progressively declines over the first year of life, but is higher in children compared to that in adults [74]. In contrast, the production of pro-inflammatory cytokines (e.g., IL-1 $\beta$, TNF- $\alpha$ ) gradually increases during early life [74] until it reaches a state of chronic low-grade systemic inflammation called "inflammaging" present in older subjects [75]. As a consequence, $\mathrm{T}$ cell responses also shift from a skewed Th2/Treg type response in newborns to a more Th1-type response in children and adults [76] with a progressive increase in effector memory $\mathrm{T}$ cell pools, which can respond efficiently to a cognate infection and are more sensitive to cytokine-mediated activation [77].

Whether the different virological and inflammatory patterns observed during the natural history of HBV infection could be explained by this age-related modulation in immune function remains to be investigated. Nevertheless, we propose that this early disease phase, characterized by high level of HBV replication and low incidence of liver inflammatory events, might be caused by the induction of an antiviral "non-inflammatory" immune response [9]. Specifically, the few and functionally impaired HBV-specific T cells may, similar to adults, try to contain the infection by cytokinedependent control and killing of HBV-infected hepatocytes. However, such responses do not trigger non-specific recruitment of inflammatory cells to the liver, possibly due to the dampened pro-inflammatory responses and the limited pool of effector/memory $\mathrm{T}$ cells present in children.

The concept that pathological processes might be modulated by age is evident in other infections. Influenza virus infection, for example, can cause death due to increased inflammatory response in the lung, thus predisposing to bacterial infection in some but not all individuals. During the 1918 influenza pandemic, it has been shown that children had a much lower mortality rate than young adults despite experiencing a higher rate of clinical influenza [78]. This phenomenon has also been observed in other bacterial and viral infections [79]. Although the immunological mechanisms underlying these differential outcomes have not been experimentally demonstrated, the emerging picture appears to be reduced pro-inflammatory responses in children than that in adults. Interestingly, it has been demonstrated, albeit in a smallscale longitudinal study, that dramatic fluctuations in serum ALT levels occur in CHB patients in the age range of 20 25 years old [51], which is the exact age window where higher pro-inflammatory events have been observed in humans.

\section{Implications for future treatment strategies for chronic hepatitis B-earlier treatment for young patients?}

Understanding the immune pathogenesis of infectious diseases in early life is required for the development of effective interventional strategies for enhancing neonatal immune responses to protect young children. Historically, the goals of therapy for CHB patients are the reduction of viremia and amelioration of hepatic dysfunction, with the hope of delaying progression to cirrhosis and the subsequent development of HCC [30]. While a "sterilizing cure" of HBV with the removal of cccDNA and integrated virus is difficult or impossible to achieve, a "functional cure" whereby patients achieve sustained suppression of HBV viremia, loss of HBsAg after a defined course of therapy, and reach a health status equivalent to a person who has recovered spontaneously from HBV infection, should at least be the goal of next wave of therapies [30].

Current guidelines from the international liver association recommend treatment for CHB patients only when they show signs of clinically active disease or development of fibrosis, typically after the age of 30 years old. However, symptoms of advanced disease often appear later in life, at a stage when little can be done to alter the disease course. This could explain the poor response rate to therapies observed in adult patients, thus highlighting the limitations of current practice and the underlying need to better define the optimal timing for treatment. At the present moment, whether young CHB patients in the "immunotolerant" disease phase are indicated for treatment remains debated. The oversimplistic view that HBV vertical or perinatal infection results in a phase of HBVspecific immune tolerance which is lost in adulthood is not supported by our increased understanding of the effect of age on the immune response, nor is it supported by our better insight into the immunological events triggered by HBV 
infection [7]. The arguments presented above challenge the concept of a generic immunotolerant state in young people and more importantly, raise questions about the premise on which treatment decisions are made.

Chronic hepatitis B infection in children or young people represents a therapeutic challenge to practitioners given the paucity of data regarding treatment in these groups of young patients [80]. Nevertheless, there are some, albeit limited, studies that show promising results. For instance, a small pilot study by Carey et al. [81] has shown beneficial responses in a proportion of "immunotolerant" children treated with a combination therapy of lamivudine and pegIFN- $\alpha$. Such beneficial responses were associated with an increase in HBVspecific T cell proliferation, reduction in HBV DNA levels, and notable increase in HBsAg seroconversion, thus providing further support for the potential benefit of early treatment in CHB patients [81, 82]. Similar studies performed in CHBinfected children have demonstrated that IFN- $\alpha$ was well tolerated, and children less than 5 years of age may have an enhanced response to IFN- $\alpha$ [83]. Likewise, the efficacy of tenofovir disoproxil fumarate was comparable between CHB-infected adolescents $(<18$ years old $)$ with that observed in adult subjects [84]. Nonetheless, long-term follow-up studies in these group of young patients is warranted to gain better insights on the rates of $\mathrm{HBeAg}$ and HBsAg loss as well as the rates of seroconversion, in order to determine whether earlier treatment is genuinely associated with better treatment outcomes.

The emerging concept of "trained immunity" discussed above [57] also has significant therapeutic implications. Rather than being immature or tolerized, we should bear in mind that the immune system of neonates or even young children is already "trained" or "matured" following birth and is actually capable of responding immunologically with broad cross-protective responses towards viral antigens. In this context, therapies that reduce the expression of viral proteins may help to "release the brakes" on the immune system of these young patients, allowing it to be fully competent to achieve long-term suppression of HBV. On the other hand, our findings that young CHB patients in the "immunotolerant" disease phase can mount $\mathrm{HBV}$-specific immune responses without inducing a full-blown pro-inflammatory reaction [69] suggest that therapeutic interventions aimed at enhancing HBVspecific immunity (e.g., vaccine therapy, checkpoint inhibitors) [12] are likely to be more effective in young CHB patients compared to adult patients. On a separate note, we should start to consider and evaluate CHB in adults in the context of an inflammatory, rather than a virus-induced disease, and as such, anti-inflammatory therapies designed to inhibit liver inflammation may turn out to be more effective in controlling HBV infection. The superior efficacy of antiplatelet therapy in blocking the development of HCC in HBV transgenic mice is one such example $[85,86]$.

\section{Conclusions and perspectives}

Chronic HBV infection is a complex dynamic disease with an unpredictable course, where the timing and most appropriate treatments continue to be debated. As we have discussed, HBV transmission at birth does not inevitably lead to the induction of a generic immune tolerant state and the inability to mount HBV-specific adaptive immunity. In addition, the detection of HBV-specific T cell response and necroinflammatory activity and fibrosis on liver biopsy in young patients are at odds with the concept of complete tolerance. These findings underscore the limited value of characterizing the disease phase solely based on clinical and virological markers, and more importantly, raise doubts about the premise on which treatment decisions are made.

A better understanding of the concept of trained immunity and how HBV establishes a permissive state in the host may pave the way for better development of therapies that are targeted towards these groups of patients currently excluded for treatment. This could potentially result in expanding therapeutic options to more patients, including treating at a younger age and at a much earlier stage of disease. Having said this, the early phase of HBV infection, i.e., from HBV-exposed newborn infants to CHB-infected children, remains an area that needs further studies. The potential role and function of many other components of the immune response, including NK and NK-T cells that are present in abundance in the liver, should also be analyzed in relation to age [87]. Should more data be available to support our stance and that earlier treatment is advocated, careful consideration should be taken into account for pediatric patients, in whom the safety, efficacy, and adverse effect profiles of antivirals have not been well established compared to the adult population.

Open Access This article is distributed under the terms of the Creative Commons Attribution 4.0 International License (http:// creativecommons.org/licenses/by/4.0/), which permits unrestricted use, distribution, and reproduction in any medium, provided you give appropriate credit to the original author(s) and the source, provide a link to the Creative Commons license, and indicate if changes were made.

\section{References}

1. Prendergast AJ, Klenerman P, Goulder PJ (2012) The impact of differential antiviral immunity in children and adults. Nat Rev Immunol 12:636-648

2. El-Serag, H. B. 2012. Epidemiology of viral hepatitis and hepatocellular carcinoma. Gastroenterology 142: 1264-1273 e1261.

3. Liaw YF, Chu CM (2009) Hepatitis B virus infection. Lancet 373: 582-592

4. Szpakowski JL, Tucker LY (2013) Causes of death in patients with hepatitis B: a natural history cohort study in the United States. Hepatology 58:21-30 
5. Bertoletti A, Hong M (2014) Age-dependent immune events during HBV infection from birth to adulthood: an alternative interpretation. Front Immunol 5:441

6. Yim HJ, Lok AS (2006) Natural history of chronic hepatitis B virus infection: what we knew in 1981 and what we know in 2005. Hepatology 43:S173-S181

7. Bertoletti A, Kennedy PT (2015) The immune tolerant phase of chronic HBV infection: new perspectives on an old concept. Cell Mol Immunol 12:258-263

8. Protzer U, Knolle P (2016) "To be or not to be": immune tolerance in chronic hepatitis B. Gastroenterology 151:805-806

9. Hilleman MR, Buynak EB, Roehm RR, Tytell AA, Bertland AU, Lampson GP (1975) Purified and inactivated human hepatitis B vaccine: progress report. Am J Med Sci 270:401-404

10. Lavanchy D (2004) Hepatitis B virus epidemiology, disease burden, treatment, and current and emerging prevention and control measures. J Viral Hepat 11:97-107

11. Fong TL, Di Bisceglie AM, Biswas R, Waggoner JG, Wilson L, Claggett J, Hoofnagle JH (1994) High levels of viral replication during acute hepatitis $\mathrm{B}$ infection predict progression to chronicity. J Med Virol 43:155-158

12. Bertoletti A, Gehring AJ (2013) Immune therapeutic strategies in chronic hepatitis B virus infection: virus or inflammation control? PLoS Pathog 9:e1003784

13. Berquist KR, Peterson JM, Murphy BL, Ebert JW, Maynard JE, Purcell RH (1975) Hepatitis B antigens in serum and liver of chimpanzees acutely infected with hepatitis B virus. Infect Immun 12: 602-605

14. Guidotti LG, Rochford R, Chung J, Shapiro M, Purcell R, Chisari FV (1999) Viral clearance without destruction of infected cells during acute HBV infection. Science 284:825-829

15. Korba BE, Cote PJ, Wells FV, Baldwin B, Popper H, Purcell RH, Tennant BC, Gerin JL (1989) Natural history of woodchuck hepatitis virus infections during the course of experimental viral infection: molecular virologic features of the liver and lymphoid tissues. J Virol 63:1360-1370

16. Thimme R, Wieland S, Steiger C, Ghrayeb J, Reimann KA, Purcell RH, Chisari FV (2003) CD8(+) T cells mediate viral clearance and disease pathogenesis during acute hepatitis B virus infection. J Virol 77:68-76

17. Whalley SA, Murray JM, Brown D, Webster GJ, Emery VC, Dusheiko GM, Perelson AS (2001) Kinetics of acute hepatitis B virus infection in humans. J Exp Med 193:847-854

18. Maini MK, Gehring AJ (2016) The role of innate immunity in the immunopathology and treatment of HBV infection. J Hepatol 64: S60-S70

19. Maruyama T, McLachlan A, Iino S, Koike K, Kurokawa K, Milich DR (1993) The serology of chronic hepatitis B infection revisited. J Clin Invest 91:2586-2595

20. Cote PJ, Toshkov I, Bellezza C, Ascenzi M, Roneker C, Ann Graham L, Baldwin BH, Gaye K, Nakamura I, Korba BE, Tennant BC, Gerin JL (2000) Temporal pathogenesis of experimental neonatal woodchuck hepatitis virus infection: increased initial viral load and decreased severity of acute hepatitis during the development of chronic viral infection. Hepatology 32:807-817

21. Menne S, Roneker CA, Roggendorf M, Gerin JL, Cote PJ, Tennant BC (2002) Deficiencies in the acute-phase cell-mediated immune response to viral antigens are associated with development of chronic woodchuck hepatitis virus infection following neonatal inoculation. J Virol 76:1769-1780

22. Nakamura I, Nupp JT, Cowlen M, Hall WC, Tennant BC, Casey JL, Gerin JL, Cote PJ (2001) Pathogenesis of experimental neonatal woodchuck hepatitis virus infection: chronicity as an outcome of infection is associated with a diminished acute hepatitis that is temporally deficient for the expression of interferon gamma and tumor necrosis factor-alpha messenger RNAs. Hepatology 33:439-447
23. Bertoletti A, Ferrari C (2012) Innate and adaptive immune responses in chronic hepatitis B virus infections: towards restoration of immune control of viral infection. Gut 61:1754-1764

24. Seeger C, Mason WS (2000) Hepatitis B virus biology. Microbiol Mol Biol Rev 64:51-68

25. Chen MT, Billaud JN, Sallberg M, Guidotti LG, Chisari FV, Jones J, Hughes J, Milich DR (2004) A function of the hepatitis B virus precore protein is to regulate the immune response to the core antigen. Proc Natl Acad Sci U S A 101:14913-14918

26. Milich DR, Chen MK, Hughes JL, Jones JE (1998) The secreted hepatitis B precore antigen can modulate the immune response to the nucleocapsid: a mechanism for persistence. J Immunol 160: 2013-2021

27. Milich DR, Jones JE, Hughes JL, Price J, Raney AK, McLachlan A (1990) Is a function of the secreted hepatitis B e antigen to induce immunologic tolerance in utero? Proc Natl Acad Sci U S A 87: 6599-6603

28. Bertoletti A, Tan AT, Gehring AJ (2009) HBV-specific adaptive immunity. Viruses 1:91-103

29. Bertoletti A, Gehring AJ (2006) The immune response during hepatitis B virus infection. J Gen Virol 87:1439-1449

30. Gish RG, Given BD, Lai CL, Locarnini SA, Lau JY, Lewis DL, Schluep T (2015) Chronic hepatitis B: virology, natural history, current management and a glimpse at future opportunities. Antivir Res 121:47-58

31. Publicover J, Gaggar A, Nishimura S, Van Horn CM, Goodsell A, Muench MO, Reinhardt RL, van Rooijen N, Wakil AE, Peters M, Cyster JG, Erle DJ, Rosenthal P, Cooper S, Baron JL (2013) Agedependent hepatic lymphoid organization directs successful immunity to hepatitis B. J Clin Invest 123:3728-3739

32. Publicover J, Goodsell A, Nishimura S, Vilarinho S, Wang ZE, Avanesyan L, Spolski R, Leonard WJ, Cooper S, Baron JL (2011) IL-21 is pivotal in determining age-dependent effectiveness of immune responses in a mouse model of human hepatitis B. J Clin Invest 121:1154-1162

33. Tian Y, Kuo CF, Akbari O, Ou JH (2016) Maternal-derived hepatitis $B$ virus e antigen alters macrophage function in offspring to drive viral persistence after vertical transmission. Immunity 44 : 1204-1214

34. Bertoletti A, Gehring A (2007) Immune response and tolerance during chronic hepatitis B virus infection. Hepatol Res 37(Suppl 3):S331-S338

35. Mold JE, Venkatasubrahmanyam S, Burt TD, Michaelsson J, Rivera JM, Galkina SA, Weinberg K, Stoddart CA, McCune JM (2010) Fetal and adult hematopoietic stem cells give rise to distinct T cell lineages in humans. Science 330:1695-1699

36. Zhang X, Mozeleski B, Lemoine S, Deriaud E, Lim A, Zhivaki D, Azria E, Le Ray C, Roguet G, Launay O, Vanet A, Leclerc C, LoMan R (2014) CD4 T cells with effector memory phenotype and function develop in the sterile environment of the fetus. Sci Transl Med 6:238ra272

37. Adkins B (2013) Neonatal immunology: responses to pathogenic microorganisms and epigenetics reveal an "immunodiverse" developmental state. Immunol Res 57:246-257

38. Luzuriaga K, Holmes D, Hereema A, Wong J, Panicali DL, Sullivan JL (1995) HIV-1-specific cytotoxic T lymphocyte responses in the first year of life. J Immunol 154:433-443

39. Marchant A, Appay V, Van Der Sande M, Dulphy N, Liesnard C, Kidd M, Kaye S, Ojuola O, Gillespie GM, Vargas Cuero AL, Cerundolo V, Callan M, McAdam KP, Rowland-Jones SL, Donner C, McMichael AJ, Whittle H (2003) Mature CD8(+) T lymphocyte response to viral infection during fetal life. J Clin Invest 111:1747-1755

40. Vermijlen D, Brouwer M, Donner C, Liesnard C, Tackoen M, Van Rysselberge M, Twite N, Goldman M, Marchant A, Willems F 
(2010) Human cytomegalovirus elicits fetal gammadelta T cell responses in utero. J Exp Med 207:807-821

41. Netea MG, Quintin J, van der Meer JW (2011) Trained immunity: a memory for innate host defense. Cell Host Microbe 9:355-361

42. Aaby P, Roth A, Ravn H, Napirna BM, Rodrigues A, Lisse IM, Stensballe L, Diness BR, Lausch KR, Lund N, Biering-Sorensen S, Whittle H, Benn CS (2011) Randomized trial of BCG vaccination at birth to low-birth-weight children: beneficial nonspecific effects in the neonatal period? J Infect Dis 204:245-252

43. Mayr A (2004) Taking advantage of the positive side-effects of smallpox vaccination. J Vet Med B Infect Dis Vet Public Health 51:199-201

44. Aaby P, Martins CL, Garly ML, Bale C, Andersen A, Rodrigues A, Ravn H, Lisse IM, Benn CS, Whittle HC (2010) Non-specific effects of standard measles vaccine at 4.5 and 9 months of age on childhood mortality: randomised controlled trial. BMJ 341:c6495

45. Wynn, J. L., N. I. Hansen, A. Das, C. M. Cotten, R. N. Goldberg, P. J. Sanchez, E. F. Bell, K. P. Van Meurs, W. A. Carlo, A. R. Laptook, R. D. Higgins, D. K. Benjamin, Jr., B. J. Stoll, H. Eunice Kennedy Shriver National Institute of Child, and N. Human Development Neonatal Research. 2013. Early sepsis does not increase the risk of late sepsis in very low birth weight neonates. J Pediatr 162: 942 948 e941-943.

46. Guo J, Gao Y, Guo Z, Zhang LR, Wang B, Wang SP (2015) Frequencies of dendritic cells and Toll-like receptor 3 in neonates born to HBsAg-positive mothers with different HBV serological profiles. Epidemiol Infect 143:62-70

47. Koumbi LJ, Papadopoulos NG, Anastassiadou V, Machaira M, Kafetzis DA, Papaevangelou V (2010) Dendritic cells in uninfected infants born to hepatitis B virus-positive mothers. Clin Vaccine Immunol 17:1079-1085

48. Zhang Z, Chen D, Yao J, Zhang H, Jin L, Shi M, Zhang H, Wang FS (2007) Increased infiltration of intrahepatic DC subsets closely correlate with viral control and liver injury in immune active pediatric patients with chronic hepatitis B. Clin Immunol 122:173-180

49. Komatsu H, Inui A, Sogo T, Hiejima E, Tateno A, Klenerman P, Fujisawa T (2010) Cellular immunity in children with successful immunoprophylactic treatment for mother-to-child transmission of hepatitis B virus. BMC Infect Dis 10:103

50. Koumbi L, Bertoletti A, Anastasiadou V, Machaira M, Goh W, Papadopoulos NG, Kafetzis DA, Papaevangelou V (2010) Hepatitis B-specific T helper cell responses in uninfected infants born to $\mathrm{HBsAg}+/ \mathrm{HBeAg}-$ mothers. Cell Mol Immunol 7:454-458

51. Wang HY, Chien MH, Huang HP, Chang HC, Wu CC, Chen PJ, Chang MH, Chen DS (2010) Distinct hepatitis B virus dynamics in the immunotolerant and early immunoclearance phases. J Virol 84: 3454-3463

52. Beasley RP, Hwang LY, Lee GC, Lan CC, Roan CH, Huang FY, Chen CL (1983) Prevention of perinatally transmitted hepatitis B virus infections with hepatitis B immune globulin and hepatitis B vaccine. Lancet 2:1099-1102

53. Mackie CO, Buxton JA, Tadwalkar S, Patrick DM (2009) Hepatitis B immunization strategies: timing is everything. CMAJ 180:196202

54. Chen HL, Chang CJ, Kong MS, Huang FC, Lee HC, Lin CC, Liu CC, Lee IH, Wu TC, Wu SF, Ni YH, Hsu HY, Chen DS, Chang MH (2004) Pediatric fulminant hepatic failure in endemic areas of hepatitis B infection: 15 years after universal hepatitis B vaccination. Hepatology 39:58-63

55. Andrade BB, Santos CJ, Camargo LM, Souza-Neto SM, Reis-Filho A, Clarencio J, Mendonca VR, Luz NF, Camargo EP, Barral A, Silva AA, Barral-Netto M (2011) Hepatitis B infection is associated with asymptomatic malaria in the Brazilian Amazon. PLoS One 6: e19841

56. Thursz MR, Kwiatkowski D, Torok ME, Allsopp CE, Greenwood BM, Whittle HC, Thomas HC, Hill AV (1995) Association of hepatitis B surface antigen carriage with severe malaria in Gambian children. Nat Med 1:374-375

57. Hong M, Sandalova E, Low D, Gehring AJ, Fieni S, Amadei B, Urbani S, Chong YS, Guccione E, Bertoletti A (2015) Trained immunity in newborn infants of HBV-infected mothers. Nat Commun 6:6588

58. Barton ES, White DW, Cathelyn JS, Brett-McClellan KA, Engle M, Diamond MS, Miller VL, Virgin HWT (2007) Herpesvirus latency confers symbiotic protection from bacterial infection. Nature 447: 326-329

59. Stabenow D, Frings M, Truck C, Gartner K, Forster I, Kurts C, Tuting T, Odenthal M, Dienes HP, Cederbrant K, Protzer U, Knolle PA (2010) Bioluminescence imaging allows measuring CD8 T cell function in the liver. Hepatology 51:1430-1437

60. Guidotti LG, Ishikawa T, Hobbs MV, Matzke B, Schreiber R, Chisari FV (1996) Intracellular inactivation of the hepatitis B virus by cytotoxic $\mathrm{T}$ lymphocytes. Immunity 4:25-36

61. Dunn C, Peppa D, Khanna P, Nebbia G, Jones M, Brendish N, Lascar RM, Brown D, Gilson RJ, Tedder RJ, Dusheiko GM, Jacobs M, Klenerman P, Maini MK (2009) Temporal analysis of early immune responses in patients with acute hepatitis B virus infection. Gastroenterology 137:1289-1300

62. Maini MK, Boni C, Lee CK, Larrubia JR, Reignat S, Ogg GS, King AS, Herberg J, Gilson R, Alisa A, Williams R, Vergani D, Naoumov NV, Ferrari C, Bertoletti A (2000) The role of virus-specific $\mathrm{CD} 8(+)$ cells in liver damage and viral control during persistent hepatitis B virus infection. J Exp Med 191: $1269-1280$

63. Webster GJ, Reignat S, Brown D, Ogg GS, Jones L, Seneviratne SL, Williams R, Dusheiko G, Bertoletti A (2004) Longitudinal analysis of CD8+ T cells specific for structural and nonstructural hepatitis B virus proteins in patients with chronic hepatitis B: implications for immunotherapy. J Virol 78:5707-5719

64. Ando K, Moriyama T, Guidotti LG, Wirth S, Schreiber RD, Schlicht HJ, Huang SN, Chisari FV (1993) Mechanisms of class I restricted immunopathology. A transgenic mouse model of fulminant hepatitis. J Exp Med 178:1541-1554

65. Sitia G, Isogawa M, Kakimi K, Wieland SF, Chisari FV, Guidotti LG (2002) Depletion of neutrophils blocks the recruitment of antigen-nonspecific cells into the liver without affecting the antiviral activity of hepatitis B virus-specific cytotoxic T lymphocytes. Proc Natl Acad Sci U S A 99:13717-13722

66. Prati D, Taioli E, Zanella A, Della Torre E, Butelli S, Del Vecchio E, Vianello L, Zanuso F, Mozzi F, Milani S, Conte D, Colombo M, Sirchia G (2002) Updated definitions of healthy ranges for serum alanine aminotransferase levels. Ann Intern Med 137:1-10

67. Gill US, Kennedy PT (2014) Chronic hepatitis B virus in young adults: the need for new approaches to management. Expert Rev Anti-Infect Ther 12:1045-1053

68. Seto WK, Lai CL, Ip PP, Fung J, Wong DK, Yuen JC, Hung IF, Yuen MF (2012) A large population histology study showing the lack of association between ALT elevation and significant fibrosis in chronic hepatitis B. PLoS One 7:e32622

69. Kennedy PT, Sandalova E, Jo J, Gill U, Ushiro-Lumb I, Tan AT, Naik S, Foster GR, Bertoletti A (2012) Preserved T-cell function in children and young adults with immune-tolerant chronic hepatitis B. Gastroenterology 143:637-645

70. Mason, W. S., U. S. Gill, S. Litwin, Y. Zhou, S. Peri, O. Pop, M. L. Hong, S. Naik, A. Quaglia, A. Bertoletti, and P. T. Kennedy. 2016. HBV DNA integration and clonal hepatocyte expansion in chronic hepatitis B patients considered immune tolerant. Gastroenterology 151: 986-998 e984.

71. Hai H, Tamori A, Kawada N (2014) Role of hepatitis B virus DNA integration in human hepatocarcinogenesis. World J Gastroenterol 20:6236-6243 
72. Milich DR (2016) The concept of immune tolerance in chronic hepatitis B virus infection is alive and well. Gastroenterology 151:801-804

73. Liaw YF, Chu CM (2017) Immune tolerance phase of chronic hepatitis B. Gastroenterology 152:1245-1246

74. Kollmann TR, Levy O, Montgomery RR, Goriely S (2012) Innate immune function by Toll-like receptors: distinct responses in newborns and the elderly. Immunity 37:771-783

75. Shaw AC, Joshi S, Greenwood H, Panda A, Lord JM (2010) Aging of the innate immune system. Curr Opin Immunol 22:507-513

76. Levy O (2007) Innate immunity of the newborn: basic mechanisms and clinical correlates. Nat Rev Immunol 7:379-390

77. Geginat J, Sallusto F, Lanzavecchia A (2001) Cytokine-driven proliferation and differentiation of human naive, central memory, and effector memory CD4(+) T cells. J Exp Med 194:1711-1719

78. Fedson, D. S. 2009. Was bacterial pneumonia the predominant cause of death in the 1918-1919 influenza pandemic? J Infect Dis 199: 1408-1409; author reply 1409-1410.

79. Fedson DS (2013) Treating influenza with statins and other immunomodulatory agents. Antivir Res 99:417-435

80. Jonas MM, Block JM, Haber BA, Karpen SJ, London WT, Murray KF, Narkewicz MR, Rosenthal P, Schwarz KB, McMahon BJ, Hepatitis BF (2010) Treatment of children with chronic hepatitis $B$ virus infection in the United States: patient selection and therapeutic options. Hepatology 52:2192-2205

81. Carey I, D'Antiga L, Bansal S, Longhi MS, Ma Y, Mesa IR, MieliVergani G, Vergani D (2011) Immune and viral profile from tolerance to hepatitis B surface antigen clearance: a longitudinal study of vertically hepatitis B virus-infected children on combined therapy. J Virol 85:2416-2428

82. D'Antiga L, Aw M, Atkins M, Moorat A, Vergani D, Mieli-Vergani $\mathrm{G}$ (2006) Combined lamivudine/interferon-alpha treatment in "immunotolerant" children perinatally infected with hepatitis B: a pilot study. J Pediatr 148:228-233

83. Kobak GE, MacKenzie T, Sokol RJ, Narkewicz MR (2004) Interferon treatment for chronic hepatitis B: enhanced response in children 5 years old or younger. J Pediatr 145:340-345

84. Murray KF, Szenborn L, Wysocki J, Rossi S, Corsa AC, Dinh P, McHutchison J, Pang PS, Luminos LM, Pawlowska M, Mizerski J (2012) Randomized, placebo-controlled trial of tenofovir disoproxil fumarate in adolescents with chronic hepatitis B. Hepatology 56: 2018-2026

85. Sitia G, Aiolfi R, Di Lucia P, Mainetti M, Fiocchi A, Mingozzi F, Esposito A, Ruggeri ZM, Chisari FV, Iannacone M, Guidotti LG (2012) Antiplatelet therapy prevents hepatocellular carcinoma and improves survival in a mouse model of chronic hepatitis B. Proc Natl Acad Sci U S A 109:E2165-E2172

86. Sitia G, Iannacone M, Muller S, Bianchi ME, Guidotti LG (2007) Treatment with HMGB1 inhibitors diminishes CTL-induced liver disease in HBV transgenic mice. J Leukoc Biol 81:100-107

87. Maini MK, Peppa D (2013) NK cells: a double-edged sword in chronic hepatitis B virus infection. Front Immunol 4:57 